\title{
Challenges of Nigerian Agricultural Sector in the Twenty First Century: The Case of Nomadic Insurgence and Terrorist Sects
}

\author{
Udemezue J. C. , Kanu N. A. \\ National Root Crops Research Institute, Umudike, PMB 7006 Umuahia Abia State, Nigeria
}

Copyright $(2019$ by authors, all rights reserved. Authors agree that this article remains permanently open access under the terms of the Creative Commons Attribution License 4.0 International License

\begin{abstract}
The challenges of agricultural sector in the twenty first century as a result of the activities of cattle herdsmen/terrorist sects should not be underestimated because they have imposed a gross untold hardship to farmers in particular and a nation at large. Nigeria has recorded several violent conflicts in many rural communities from 1999 till date, conflicts that have resulted to over 10,000 deaths and internal displacement of over 300,000 Nigerian have been recorded and this has created distortion in farmer's livelihood since they live and earn their living from rural areas. Presently, the current situation of agriculture in Nigeria is despicable, deplorable, unspeakable, disgraceful, deceptive, tragic, retrogressive and not even befitting a nation that is rich and endowed with natural resources. However, the implications of cattle-herdsmen/terrorist sects on agricultural sector have displayed consequent effects in all the spheres of agricultural fields and even brought about fundamental problems with regard to food crisis in the prone areas. In view of this, this paper used analytical approach to review the followings; Impacts of cattle herdsmen on Nigerian economy, Causes of farmers-herder's Conflicts in Nigeria, coping strategies for the challenges and the detailed report on the number of attacks and number of people killed by cattle herdsmen in the last 5 years. This paper therefore, recommended that those factors that cause or escalate conflicts must be seriously avoided and if probably occur should be entrusted in the hands of the traditional rulers of the community involved. Government at all levels should handle conflict with their utmost capacity thereby enacting laws that will serve as deterrent to cattle herdsmen in order to reduce insecurity and ameliorate the spate of conflict and mass slaughter. Traditional method of conflict management should be articulated with modern ones in order to stop further eruption of conflicts. Establishment of ranches in all the states of nation should be enacted into law to reduce the spate of conflicts escalation.
\end{abstract}

Keywords Challenges, Agricultural Sector, Cattle
Herdsmen in Nigeria

\section{Introduction}

Before the advent of oil boom in the 1970s, Agriculture was the major sector upon which majority of Nigerian population relied on for their livelihood [28]. Agriculture was able to grow at a sufficient rate to provide enough food for the increasing population, raw materials for industries, increasing public revenue and foreign exchange for government and employment generations for the teaming population. This has been a dramatic increase in the incidence and severity of poverty in Nigeria today, and this occasioned by the dwindling performance of the agricultural sector where the majority of Nigerians relied on national cake (oil boom) for their daily income. The role of Agriculture in accelerating economic growth and the development process of any nation should not be taken for granted, because it is the bedrock upon which countries depend on for their economic growth and restructuring. Therefore whatever affects agricultural sector indirectly affects the country's economy directly and this could bring about food insecurity in totality.

Rural farmers and livestock breeders are the major sources of food in Nigeria. Conflicts between pastoralists and famers have been in existence since the beginning of agriculture because a greater percentage of Nigeria population relies so much on it for nation building. However, increase in the herd size due to the improved conditions of the cattle made the cattle herders to look for more pasture beyond their limited ranch, on the other hand, improvements in the human health and population have imposed so much greater pressure on farming land and this be the reasons the farmers and nomads were at incessant conflicts over the limited land [5]

The challenges of agricultural sector in the twenty first 
century due to the activities of cattle herdsmen and terrorist insurgence have imposed more security threats than safety to the mankind because they have created a severity of untold hardship to farmers in particular and a nation at large. According to [8], Nigeria has recorded several violent conflicts in many rural communities from 1999 till date, conflicts that have resulted to over 10,000 deaths and internal displacement of over 300,000 Nigerian have been recorded and this could create distortion in farmer's livelihood since they live and earn their living from rural areas.

Nigeria has about 22 million cows that consume at least 1 billion gallons per day of water and 500 million kilograms of grass and forage crops. The intensification of the Boko Haram crisis in the last five years has caused nomadic Fulani herdsmen to abandon their foraging grounds in the North East. Climate change has caused desertification in the far north, and has led to extended drought and an estimated $20 \%$ drop in crop yields across the rest of Nigeria [15].

For the last 5 years, the Boko Haram crisis has had a profound impact on northern Nigeria, specifically the North Eastern states of Bauchi, Borno, Yobe, Gombe, Adamawa and Taraba. As the sect rampaged through the North East, communities were destroyed and spread insecurity across the region. Cattle rustling increased, millions of people were displaced from their communities, farm lands were abandoned, and a land mass that is almost $15 \%$ of Nigeria has essentially become a no - go area for nomadic herdsmen. The North Eastern region of Nigeria has some of the richest foraging stock in the country - and much of that is no longer available for use - because of the Boko Haram crisis [15]. The implication has been a downward, southwards movement by nomadic Fulani herdsmen as they move in search of water and foraging resources for their cows and this has led to intensification of resource pressures on north central and southern communities, culminating in violent struggles that have led to an estimated 89,000 deaths since 2005 . Indiscriminate cattle grazing has also contributed to the destruction of vegetation and wildlife habitats, and led to the pollution of farms, rivers and waterways with cattle manure across many communities. However, Communities have experienced ecological and economic devastation as a result of this crisis. Therefore, the combination of a growing cattle population, the effects of climate change on the availability of water and forage crops, as well as the lack of access to North Eastern foraging grounds due to the Boko Haram crisis are the proximate causes of the increasing tensions between farming communities and cattle herdsmen [15].

On the other hand, land use principles have seen as one of the major principles that brings about conflicts between farmers and cattle herders in Nigeria. Land fertility is a united factor to be considered in an attempt to understand how land use principles and practices are perceived.
Agronomists and pastoralists tend to be different from each other both in regarding principles and practice of land use. In Anambra state, Ayamelum local government to be specific, many disputes occur during dry seasons when farmers are planning to harvest crops and at the same period, the herdsmen are wandering to feed their cows on the crops. However, if crop damages occur, farmers may claim right to fight that the herdsmen should stop destroying their crops and when this happens, the herdsmen may also perceive this act as an intimidation to them. More so, conflicts could also erupt when some vegetable farmers living around riverside claim right to grow vegetables around the water side that the herdsmen should not destroy their vegetables in order to give their cattle water. As regard to this, [3] saw lack of agreement in the principles of land use as the cause of the conflict between farmers and pastoralists. Therefore, it is important to know the difference perceptions of land use principle and practices in the study of dispute settlement. The way by which people perceive land culturally may be instrumental to know how disputes between agronomists and pastoralists can be managed [33]. In an extension to the cause of conflict between Fulani herdsmen and farmers, it appears to be no consensus among both groups as to the cause of their mutual conflicts. According to [11], destruction of crops by cattle and other farming properties (irrigation equipment and infrastructures) by the cattle herders themselves were the major causes of conflicts cited by the farmers. Burning of range land, blockage of the stock route and water point were the another causes of conflicts reported by the cattle herders.

Whatever the causes of farmers-herdsmen conflicts may be, it is evident that conflicts have been of great negative effects (loss of income/resources yield) to physical effects (such as home/ farm destruction, body injury or death of family members) and socio-psychological effects like emotional exhausted, job dissatisfaction, among others [2]. Therefore, it was on these existing problems that this paper was incubated and hatched to carry out research on the challenges of Nigerian agricultural sector in the twenty first century, the case of nomadic insurgence and Boko Haram.

\section{Impacts of Cattle Herdsmen on Nigerian Economy}

Agriculture was the pillar sector of the Nigerian economy which accounted for more than $70 \%$ of the Cross Domestic Product (GDP) and more than $75 \%$ of Nigeria's export earnings before Nigerians' independence in 1960 . However, Agriculture accounted for $62.50 \%$ of the nation's GDP between 1960-1964 and thereafter its contribution to GDP started decreasing from 1970 to 1975 as a result of oil boom in Nigeria [19].Presently, the current situation of agriculture in Nigeria is despicable, deplorable, unspeakable, disgraceful, deceptive, tragic, retrogressive 
and not even befitting a nation that is rich and endowed with natural resources. The implications of cattle-herdsmen on agricultural sector have displayed consequent effects in all the spheres of agricultural fields and even brought about fundamental problems with regard to food crisis in the prone areas. Frustrated farmers can go to war because whatever happens to their farms indirectly appears to them directly. Hence, Violent- conflict is the major hindrance to national development in the $21 \mathrm{st}$ century; it leaves human being into suffering and climate of fears through death, destruction of livelihood, detailed economic challenges, constant displacement and insecurity. Farmers in Nigeria today face challenges and these hamper the productivity that consequentially affects the Nation's economy.

The activities of nomad in Nigeria since the 1960s have fundamentally undermined the stability and development of Nigerian state and economy. The social, economic, and political tension created as a result of numeral escalations of violent conflict have raised fundamental national questions for survival of the Nigeria state [13]. However, once conflict launches into agricultural system as a result of the activities of cattle-herdsmen, issues set in, farmers can lose focus on the result they supposed to achieve. Owing to this, it leads to total conflicts between farmers and cattle-herdsmen which in return cause low productivity among farmers. Conflicts distort the economy and worsen income inequality of rural farmers. It is a big challenge which had eaten deep into every fabric of all facets of agricultural production. However, activities of cattle herders and Boko Haram insurgence on crop production can distort economic growth thereby placing a nation into economic disarray that can cause food insecurity in general.

In the light of this, [17] opined that farmers-herdsmen conflict did not only have direct impact on the lives and livelihoods of those involved but also disrupt and threaten the sustainability of agricultural and pastoral production in West Africa. On contrary, [21] also saw conflicts between cattle herders and farmers as something that undermines the impact of agricultural extension service delivery and innovative usage among farmers in Nigeria. A study conducted by him shows that majority $(77 \% .8 \%)$ of farmers in the study area perceived conflict as a loss while about $(68.4 \%)$ of the herdsmen also saw it as a threat. This shows that both parties did not see conflict as an avenue to gain or progress in all ramifications.

Between 1990-2014, the conflicts between farmers and cattle herdsmen in Ayamelum local government Area, Anambra state Nigeria have claimed several lives, wounded over 100 people, destroyed many properties and also displaced a lot of pastoralists from their temporary abode [28]. More so, they also shown that majority of the farmers perceived the effect of conflict as loss of crop yield, loss of soil fertility, environmental pollution, loss of income and farm destruction. Farmer-herdsmen conflict significantly had impact on agricultural production particularly on the farmers' household in Nigeria. As farmers did not perceive it as an opportunity to gain rather they saw it as an impediment to rural development. Hence, it is important to note that these conflicts have direct impact on the lives and livelihoods of those involved. Conflicts reinforce circles of extreme poverty and hunger, and destroy social status, food security and affect mostly the most marginalized groups that include women and children. This affects education of children leading to obstacles in their development and mass displacement. This awful situation becomes worst, especially when either the farmer or the pastoralist is categorized into a group relating to religion, tribe or region. Based on this, [1] opined that the disharmony in pastoralists and farmers enhanced constant conflict with the agrarian societies.

From the year 2000 to 2015, there have been reported cases of conflicts and confrontation between the Fulani's and the indigenes of the areas they migrated to. The media (print and electronics) is awash with reported cases of clashes between the Fulani's from the North and the inhabitants of the Plateau, Kogi and Benue in the middle belt region of the country and some parts of the Eastern region. The Sun Newspaper of June 30th, [25] reported of clashes between the Fulani's and the Agatu people of Benue state and the clashes left several people dead. In the eastern parts of the country, like, Uzouwani, Ezeagu, Umuahia to mention a few, such clashes has not gone unnoticed. In 2013, the press media reported that the Fulani's killed 2 people in Uzouwani local government of Enugu State, 1 in Ezeagu and caused great damage to crops in Umuahia, Abia State. The case of Benue State is pathetic as the Fulani's has become an army of occupation to the inhabitants of the areas.

Still in the same year, no month passes without report of conflict between the pastoralists and the indigenes of the regions. From Plateau to Nasarawa, Benue, Taraba, Enugu, Anambra, Abia, Imo state, the media is awash with reports of conflicts between the duo and the conflicts often result in the death of pastoralists themselves, many farmers and their families and sometimes the entire host communities as observed in Benue and Plateau states. Daily Sun of the 20th may 2015, reported that 38 people were killed in Benue, Taraba, by Fulani herdsmen. This captured the ugly scenario going on in the regions. Since 2000 till date, two hundreds of people (Farmers and their Families and even the pastoralists) have lost their lives in conflicts arising from the grazing by the herdsmen cattle.

In the same vein, other resources worth millions of naira had been lost and thus increasing aggressive poverty in the affected regions. Considering the number of people killed by these conflicts and confrontation, it becomes glaring that the human resource that engaged in economic activity in the nation have been depleted, can no longer engage in their usual economic activities and thereby reducing the productive and economic strength of the nation. More so, 
the presence of cattle herdsmen in the affected areas creates climates of fear as they possess sophisticated arms and ammunitions with which they use to unleash terror on the people of the regions and other perceived enemies [7].

Crisis associated with pastoral migration and grazing conflict between cattle herdsmen and local farmers has been reported more in the Benue-Plateau area than the eastern region of Nigeria. Between 2000 AD and 2015, No month passes without skirmishes being reported between Fulani herdsmen and the indigenous people of Benue and plateau State. The crisis has been resulted from the fact that the Fulani herdsmen having invaded the area unleashed their cattle on the farms of the Tiv and this leads to loss of agricultural product. For instance, vanguard edition of 7 th April,[32], reported that suspected Fulani herdsmen killed 28 people, injured many in Benue, sacked (3) three villages in Governor elect, Ortoms home town. The sun edition of the same 27th April [26], reported that suspected cattle herdsmen attacked Benue community; Adeke, Mbadiwan, in Gurua district of the local government, killed several people and injured many. According to the paper, the attack left the community in ruins. The most significant areas affected in the continuous attack over a decade are, Benue and Plateau States. In Enugu State, 2009, suspected cattle herdsmen attacked Ezeagu communities in the State and kill about two women in their farm. The sun edition of June [24], reported that the women killed in the farm reacted against the grazing of the Fulani cattle's in their farm. The herdsmen got enraged and in the end, the two women were killed. The resultant of this killing led to the expulsion of the entire Fulani herdsmen from the area.

In Anambra State, especially Anambra east, the activities of Fulani herdsmen have also been reported in the media. For instance, in Aguleri/Umuleri axis, Fulani herdsmen have been banned from entering the area since 2012. This area is known for high agricultural engagement and food production like rice, yam and others are grown in high quantity. The damage caused by Fulani herdsmen also led to their expulsion from places like Umuahia and Isuochi precisely as they have all witnessed orgy of violence and crisis of greater magnitude caused by the cattle herdsmen. Both Aguleri and Unuleri axis in Anambra State; Uzouwani and Ezeagu in Enugu State have not tolerated the incursion of the cattle herdsmen in their area. Another conflicts between farmers and cattle herders in Miga, Kaugana, Birni Kudu, Garki and Maigatari Local Government areas of Jigawa state claimed many lives, and properties that estimated to N1.56 billion [13]. In 2002 pastoralists were derived out of Basa local government Kogi state after a bloody encounter with farmers. Between 1996 and 2002, another 49 cases of conflicts between farmers and pastoralists were reported in Kogi state [4]. In the year 1999 plateau state and pastoral fulb were in conflict due to the eruption of the ethnic religious crises which led to driving many pastoralists out of their domain and killing of their cattle with chemicals. All these have produced adverse consequences in the destruction of villages, settlements, crops, irrigation facilities human beings and Animal lives therein. In 2009, hundreds of pastoral Fulbe were expelled from Demboa Local government of Borno state as a result of the conflict between farmers and cattle herdsmen. However, the invasion of Tipo, Kisa, Samne, bangi Wurke and Gure communities in Lamurale local government area of Adamawa state by cattle herders with guns left unconfirmed number of death and injured persons with over 2000 people rendered homeless due to the destruction of their village [18].

In 2016, anxiety and confusion engulfed Abbi Community in Uzo Uwani Local Government Area in Enugu state due to the invasion of the area by Fulani herdsmen who launched attack on the people, killing a brother and sister apart from setting ablaze on about seven houses and other valuable properties. About 19 persons where declared missing in the community even as several other people were also wounded with cutlass and gun by the cattle herders [31].Eight persons were killed, many injured, houses and farm razed as Fulani herdsmen attacked four villages (Tsechia, Tsenhu Mbe, Deghkia and Ngorukgan) in logo local government area of Benue State, Nigeria in 2016.

In the same vein, about ten persons were killed and over 300 persons were also rendered homeless in the outbreak of fresh hostility between cattle herdsmen and Farmers at Tom-Anyiin and Tom-Ataan community, Mbaya Tumbu in Buruku local government area Benue state, Nigeria,[31]. However, a source from one of the effected community said that cattle herdsmen stormed the community late Sunday night shooting sporadically and burning down houses, huts, food barns, farms and economic trees. According to the eyewitnesses in August 6, 2016, 10 persons were killed in Igbariam Community, 7 persons in Ummumbo community and about 10 hectares of rice field were burnt including more than 30 persons who were injured by herdsmen invaders in Ugbenu Community all in Anambra State Nigeria.

The movement of cattle herders for pasture into various parts of Nigeria has been accompanied with attendant challenges and opportunities for both the farmers and pastoralists. However, the movement has brought about conflicts and wars to further emergence of the state of insecurity, political instability, social upheaval and socio-economic quagmire. More so, the conflicts have demonstrated high potential to cause food crises and insecurity in rural communities where majority of the conflicts frequently occurred. It portends a grave consequence for rural development as well as imposing threat to various aspects of human life.

With respect to the above, it is pertinent to know that whatever the consequences may be, farmers and herdsmen suffered several negative socio-psychological consequences relating to their family lives, because 
whatever happens at work could automatically affect what happens at home. To support this, [28] opined that it is absolute impossible to find a frustrated person at work who is still energetic at home and these effect farmers more than herdsmen, probably due to the fact that farmers suffered more losses than herdsmen. In all, conflict between crop farmers and cattle herdsmen over the use of agricultural land is still pervasive and has created grave consequences for rural development. However, since rural development is a prerequisite to economic growth and nation building in totality, therefore, whatever affects it indirectly, affects economy directly because rural people control about $70 \%$ of Nigerian economy.

\section{Causes of Farmers-herder's Conflicts in Nigeria}

There have been clashes between cattle herdsmen and the farmers in several parts of Nigeria for over three decades. The clashes are occasioned by the destruction of agricultural farms of the farmers by the cattle. Naturally, cattle herders by their nature are migrants who leave their traditional abode in search of greener pasture for their flocks. The migration is caused by the absence of good and vegetable land for their flock to feed on. For instance, the rate of desertification and deforestation in the Sahara desert is at an alarming rate and Nigeria is part of the countries of the Sahel region that experiences drought, desertification and deforestation. These triadic challenges mentioned above forced the cattle herders who occupy the area to migrate down south for greener pasture for their cattle to graze. In the course of entering the shores of the southern and middle-belt regions of the country, their cattle cause great damage to farm land, resulting to conflicts between them and the indigenes [23]. With the available literature, there are a number of factors that provoke the escalation of conflicts in Nigeria; Religious and ethnic related issues which account for about $40 \%$ of conflict (b) land related conflict account for about $50 \%$ of the whole conflicts [18]. According to Blench (2010) there were sporadic incidents of conflict between the Mambila farmers and pastoralists as far back as 1923 when Fulbe allowed their cattle to trample on crops. The obstruction of Fulb movement around valleys led to the last culminating in burning down of Mamabila village and among other things. More so, in Anambra State, it has been observed that between 1990-2014, the conflict between farmers and herdsmen in Ayamelum local government of Anambra State have claimed several lives, wounded over 100 people, destroyed many properties and caused displacement of pastoralists from their temporarily abode due to destruction of farmers' crops, raping of female farmers, environmental pollution, and destruction of other valuable properties by the cattle herders [29]. Their crop is their life, because to every farmer, life is worthless without his crop. Therefore, war is their next option when their source of existence is destroyed.

Herder - Farmer conflict not only have a direct impact on the lives and livelihoods of those involved but also disrupt and threaten the sustainability of agricultural and pastoral production in west Africa. Therefore, it is unjust and unwise to ignore the proximate cause of the conflicts between farmers and herdsmen because what we regard as local conflicts may escalate into real war. However, we need to know not just why friction begins, but also why and how conflicts between herders and farmers escalate into widespread violence. With the available literature, herders and farmers in many localities make their livelihood within the same geographical, political and socio-cultural conditions which may be characterized by the scarcity of resources and this gives rise to conflicts between farmers and herdsmen [9]. In 2004, president Obasanjo of Nigeria declared State of emergency in central plateau state, when there were herder-farmer conflicts which more than 20,000 refugees fled to neighboring Cameron and this articulated with ethnic, political and religious conflicts characterized the state [17]. In Ghana, crop damages have on numerous occasions resulted in widespread violence among farmer, youths and cattle herders [27]. Moritz [17] also identified many structural factors that contribute to the increasing incidence of conflict between herder and farmers as follows; Resource scarcity, decreasing interdependence of pastoral and agricultural economies, institutional failure to resolve conflicts and cultural differences between herders and farmers. Bassett [6] saw drought and high cereal price as the proximate cause of the conflict between herders and farmers. In the same Vein, [16] identified incompatibility as one of the causes of the conflicts between farmers and herders. Since the goals of both parties are incompatible, it is likely that they would compete with one another over natural resources, which thereafter result to escalation of conflicts. The influx of cattle herders, the growth of their herds, and the expansion of cash crop production has led to greater competition over land between Grass field subsistence farmers and Fulani herders. According to Goheen [12], gender is an important variable in herder-farmer conflicts in the Grass fields of Northwest Cameroon because subsistence farmers are primarily women and Fulani herders are men. In some parts of Cameroon, women have limited rights over land and because of this the fon and lineage chiefs receive tribute for allocating farm land to Fulani very close to women farm. As a result, women's work load increases and conflicts with herders are almost inevitable [14]. According to De Haan [11], destruction of crops by cattle and other property (irrigation equipment and infrastructure) by the pastoralists are the main direct causes for conflicts cited by the farmers, whereas burning of rage land and fadama and blockage of stock routes and water points by crop encroachment are important direct reasons cited by the pastoralists. He also 
noted that antagonistic perceptions and beliefs among farmers and herdsmen could compound conflict situation. Other perceived causes of farmer-herdsmen conflicts include: inequitable access to land, diminishing land resources, antagonistic value among user groups, policy contradictions and non-recognition of rights of indigenous people [2]. In general, Conflict theorists have offered three general models for conflict escalation: contender- defender model, the conflict spiral model and the structural change model [20]. Contender- defender model views conflicts in terms of the actions of one party (the contender) who seeks changes and the reactions of the other party (defender). Contender uses more of coercive strategies to attain his goals. The conflict spiral model focuses on the interaction between the two parties, in particular the vicious circle of actions and reactions of retaliation and deterrence. The structural change model focuses on psychological changes that take place in the parties as conflict process. The psychological changes involve emotion, attitudes, perceptions and behavior of individuals.

Whatever the causes of farmers- herdsmen conflicts are, it is good to know that the conflicts have been of great negative effects on human lives and agricultural development. Therefore, for both parties to conform with federal government's agricultural transformation agenda they should eschew conflicts and embrace peace. Based on this, it is therefore pertinent to know that if the conflicts between farmers and cattle herdsmen are properly managed, it will exploit agriculture to ensure food security and also be a catalyst to move national economy towards a positive change as well making agriculture a pivot for rural development.

\section{Coping Strategies for the Challenges}

Nigerian government believed in resolving conflicts by using force, but international communities have gone above the levels of brute force [8]. The use of brute force cannot offer a lasting solution to the problems but can only escalate the conflicts situation in the area. For instance, the brute force employed by the security agents during Tiv and Jukun conflicts management led to destruction of properties and extra-judicial killings. Therefore, it should be noted that whichever the resolution approach used there is need for all the parties involved to have consensus on how to bury the cause and the effect of the conflicts to eschew further conflicts escalation. In the light of the above, some of the copping strategies are; Early harvesting method, supplementary occupation, use of traditional rulers, use of physical fight by the farmers, use of security agents, increase farm size, use of police, setting up panel of inquiries, use of bamboo fence, spreading cattle's defecation on the crops, help from the village youths, temporary relocation of farmers from home and use of court order.

\section{Detailed Report on the Number of Attacks and Number of People Killed by Cattle Herdsmen in the Last 5 Years.}

July 2012: Senator Gyang Dantong and the Majority Leader of the Plateau State House of Assembly, Mr. Gyang Fulani died in the stampede when attending the mass burial of about 50 victims of attack by cattle herdsmen at Maseh village in Riyom LGA.

April 23, 2013: 10 farmers killed in an attack in Mbasenge community, Guma L.G.A by suspected herdsmen.

May 7, 2013: 47 mourners gunned down by suspected herdsmen in Agatu while burying two policemen.

May 14, 2013: Over 200 herdsmen surround Ekwo-Okpanchenyi, Agatu LGA killing 40 locals.

July 5, 2013: 20 people were killed in a conflict between Tiv farmers \& herdsmen at Nzorov, Guma LGA.

July 28, 2013: In retaliation to the alleged killing of 112 cows, herdsmen invade 2 villages in Agatu LGA killing 8 villagers.

November 7, 2013: Attackers strike at Ikpele \& Okpopolo communities killing 7 and displacing over 6000 inhabitants.

November 9, 2013: 36 locals killed, 7 villages overrun in an outbreak of fighting between herdsmen and locals in Agatu L. G.A.

June 2015: Cattle herdsmen attacked Motokun village, Patigi Local Government Area, Kwara State. The Oro-Ago community in Ifelodun Local Government Area of the state was also attacked. Cattle herdsmen attacked Ninji and Ropp villages in Plateau State and killed 27 persons. Also, the same group reportedly murdered about 70 Christians.

July 16, 2015: Cattle Herdsmen attack and killed farmers in Plateau.

September 2015: An attack by some catte herdsmen on the community of Onitsha Ukwuani in Ndokwa West local government area of Delta State left about three persons dead. A middle-aged woman was raped and subsequently killed by three cattle herdsmen in Edo state.

October 2, 2015: Cattle Herdsmen raped, killed Ogun Residents and Farmers.

November 2015: Herdsmen invaded Ulaja and Ojeh communities in Dekina Local Government Area of Kogi State and killed about 22 men and women.

December 1, 2015: Cattle Herdsmen kill a man in Ofagbe community, Isoko North council area of Delta.

January 24, 2016: Nigerian police DPO, 29 others killed by suspected cattle herdsmen.

February 2016: Cattle herdsmen reportedly killed About 10 persons in Tom-Anyiin, Tom-Ataan, Mbaya and Tombu in the Buruku Local Government Area of the state.

February 8, 2016: 10 killed, Over 300 displaced in clash between herdsmen and farmers at Tom-Anyiin, Tom-Ataan in Buruku LGA.

February 11, 2016: Herdsmen attacked Abbi community 
in Uzo-Uwani LGA, Enugu killing two siblings and burnt houses, motorcycles.

February 29, 2016: Over 500 locals killed and 7000 displaced in an attack in Agatu LGA by cattle herdsmen.

March 9, 2016: 8 residents killed during herdsmen attacks in Ngorukgan, Tse Chia, Deghkia and Nhumbe, Logo LGA.

April 5, 2016: APC youth leader, Mr. Aondohemba Kasa and 3 others killed in fresh cattle herdsmen, farmers' clash in Benue.

April 8, 2016: Cattle herdsmen kidnapped and killed Falae's security guard at his Ondo state farm.

April 9 2016: Fulani camp was razed following the killing of a 64-year old farmer, identified as Alex in Edo.

April 12, 2016: Fulani herdsmen attack Dori and Mesuma villages in Taraba, killing at least 15 .

April 19, 2016: A member of about 18 suspected Herdsmen that invaded farms in Lagun village, Lagelu local council Oyo state, shot Mr. Jimmy Aido.

April 25, 2016: 48 killed, 60 injured by cattle herdsmen in Ukpabi Nimbo community, Enugu state.

April 27, 2016.six more bodies recovered in Enugu state, death toll was forty six. Governor, Ugwuanyi, declared two-day fasting and prayer in respect to the victims of the people killed by cattle herdsmen.

\section{Source}

http://www.igbounioncanada.com/biafra-news/nigeria-enu gu-killings-by-fulani-herdsmen-gruesome-pictures.html.

Sun Newspaper of June 6, 2009,Sun Newspaper of June 30th, 2014,Sun Newspaper of may 20th, 2015, Daily sun newspaper of 27th April,2015, Vanguard newspaper of February8,2016 and Vanguard newspaper of 27th April ,2016

\section{Conclusions}

Cattle herders/boko Haram sects have done more harms than good in our social life today, especially in agricultural sector that stands the roots of every nation. The implication affects everybody in all ramifications, even the perpetrators themselves; therefore, the moment we salvage/overhauled our country from these adverse effects, the better for our livings. Agricultural economy controls other economies, therefore, whatever profession a person belongs to or practice, such a person should know that everybody is a stakeholder in agriculture and such profession should be prioritized for the benefit of mankind. The destruction in the farming system has impacted negatively on Nigerian economy and an urgent remedy has to be taken to get out of the ruins. In the light of this, it is pertinent to note that both the migrant pastoralists and the indigenes all constitute human resources of the nation and both contribute individually or collectively to national development. While the migrant pastoralists are carrying their cattle to graze in the regions, the owners of the land, especially the farmers are heavily affected as the herdsmen cattle destroys crops, farm land and other agricultural products which often results to conflicts and confrontation. This paper used analytical approach to discuss; the impacts of cattle herders to Nigerian economy, the causes of conflicts between cattle herders, farmers and the coping strategies for the conflicts as well as the detailed report on the number of attacks and number of people killed by cattle herdsmen in the last 5 years.

\section{Recommendations.}

* Those factors that cause or escalate conflicts must be seriously avoided and if probably occur should be entrusted in the hands of the traditional rulers of the community involved.

* Government at all levels should handle conflict with their utmost capacity thereby enacting laws that will serve as deterrent to cattle herdsmen in order to reduce insecurity and ameliorate the spate of conflict and mass slaughter.

* Traditional method of conflict management should be articulated with modern ones in order to stop further eruption of conflicts.

* Establishment of ranches in all the states of nation should be enacted into law to reduce the spate of conflicts escalation.

* Both state and federal should create enabling environment for compensating the victims of the insurgence.

\section{REFERENCES}

[1] Abbass, I. M. (2012). No Retreat No Surrender: Conflict for Survival between Fulani Pastoralists and Farmers in Northern Nigeria. European Scientific Journal, Vol. 8, No. 1, pp. 331-346.

[2] Adisa, R. S. (2011). Management of Farmer-herdsmen Conflict in north-Central Nigeria: Implications for Collboration between Agricultural Extension Service and other Stakeholder. Journal of international Agricultural Education and Extension 18 (1): 60-72.

[3] Agboola, A. A and Eniola, H. T. (1992). Technology generation for small-scale farmers in Nigeria in Olukosi and Kanu. Proceedings of Nigerian National Farming System Research Network held in Calaba, Cross River State, Nigeria.

[4] Ajuwon, S. S. (2004). Managing conflicts of interest in community Development: Conflict in Fadama community-case study on Fadama conflict issues, http:info.worldbank.org/etools/docs/library/39228/conflict. $20 \%$ Fadama $\% 20$ management.doc.file//localhost/f:conflict 
124 Challenges of Nigerian Agricultural Sector in the Twenty First Century: The Case of Nomadic Insurgence and Terrorist Sects.

$\% 20 \%$ Fadama $\% 20$ Areas $\% 20$ Srpeache.htm.

[5] Alhassan, U. (2013). Hersmen and farmers' conflicts in north- Esthern Nigeria. Causes, repercussion and resolutions. Academic journal of interdisciplinary studies, volume 5 (3) pp $342-353$.

[6] Bassett, T.J. (1998). The political Ecology of Peasant herder Conflicts on the Northern Ivory Cost. Annuals of the Association of American Geographers (78): 453-472.

[7] Blench, R. (2010). Conflict between Pastoralist and Cultivation in Nigeria, Kay Williamson Educational foundation Cambridge,

hhtp:www.orgerbtenchinfor/RBOP.htm

[8] Bolarinwa,k. Oluwakemi, E and Foloruso, B (2012). Conflict resolution strategies among farmers in Taraba State, Nigeria.

[9] Braukamper, U. (2000) Management of Conflict over pastures and Fields Among the Baggara Arabs of the Sudan Belt Nomadic people 4 (1): 37-49

[10] Daily sun newspaper of $27^{\text {th }}$ April, 2015.

[11] Dehaan, C (2002). Nigeria Second Fadama Development project (SFDP), project preparation Mission Report Livestock component, World Bank. pp 1-13

[12] Goheen, M. (1996). Men Own the Fields, Women Own the Crops. Madison: university of Wisconsin press.

[13] Isa, M. A (2013). No Retreat No surrender conflict for survival Between Fulani Pastoralists and farmers in Northern Nigerian. European Scientific Journal January edition vol. 8. No 1 .

[14] Kum, J. S.E. (1983). The farmer-Grasjier Dispute in Aghem: An Ethnic or an Economic problem? M.A. Thesis, University of Yaounde.

[15] Malcolm, F and Adeleke, O (2016). Why the Fulani Herdsmen \& farmers fight: How climate change \& the Boko Haram crisis created the crisis and six evidence-based policy recommendations for its resolution. Available at www.why-fulani-herdsmen-farmers-fight-how-climate-cha nge-boko-haram-crisis-created-crisis-and.htm

[16] Mitchell, C.R. (1981). The structure of International Conflict. New York: St. martin's Press

[17] Moritz, M. (2010). Understanding Herder-Farmer Conflicts in West Africa: Outline of a procession Approach Human Organization Vol. 69, No 2.

[18] New Nigerian (2010). "30 injured in Adamawa cattle Rearers Invasion” Monday February 1st, 2009.
[19] Okonkwo, J.C. (2015). Root and Tuber Crops Production and Value Chain Creation. Dependable Thrust o Nigeria's Agricultural beyond Oil. Proceedings of the 49th Annual Conference of the Agricultural Society of Nigeria. Delta State, Nigeria. pp15.

[20] Pruitt, D. G and Kim, S. H (2004). Social Conflict: Escalation Stalemate, and Settlement. Boston, mass: McGraw-Hill.

[21] Rashid, S.A. (2007). Management of Farmer-herdsmen conflict in north central Nigeria: Implications for Collaboration between Agricultural Extension Services and other stakeholder. JIANEE Volume 18 Number 1

[22] Schmidt, W. H. (1974). Conflict: A powerful process for (good or bad) change management Review issue.

[23] Solomon, O. A. and Chinwe, O. O. (2015). Climate change and pastoral conflicts in the middle belt and South-East Nigeria: Implication on human resource of the regions. Global Journal of Human Resource Management Vol. 3, No. 5, pp. 44-51.

[24] Sun Newspaper of June 6, 2009,

[25] Sun Newspaper of June 30th, 2014,

[26] Sun Newspaper of May 20th, 2015,

[27] Tonah, S. (2006). Migration and herder- farmed conflict in Ghana is Valta basin. Canadian Journal of African Studies 40(1): $152-178$.

[28] Udemezue, J. C. and Anedo, E. N (2015). Effect of farmers' conflicts with Fulani herdsmen on agricultural development in ayamelum local government area, anambra state, Nigeria. Igboscholars international journal of igbo scholars forum Nigeria. vol. 2 NO. 1. pp 169-179.

[29] Udemezue, J. C. and Anedo, E. N (2016). Farmer-cattle herdsmen conflicts: causes, management and implications on agricultural system in ayamelum local government area of Anambra State, Nigeria. Ideal international journal Volume 1, No 2. pp 43-56

[30] www.igbounioncanada.com/biafra-news/nigeria-enugu-killi ngs-by-fulani-herdsmen-gruesome-pictures.html

[31] Vanguard newspaper of February 8, 2016,

[32] Vanguard newspaper of 27th April, 2016.

[33] Yahaya, m. k. (2005).land, Agriculture and conflict Nexus in Africa: lesson from Zimbabwe experience in I. O. Albert (ed) perspective in peace and conflict in Africa. Essay in honor of general Abdusalam Abubaka, Institute of African studies U. I Ibadan 